\title{
Changes of MAO-A and MAO-B Expressions in the Placenta of MPTP or MPP ${ }^{+}$Treated Mice
}

\author{
Takafumi Sai ${ }^{1,2 *}$, Kazuyuki Uchida ${ }^{1}$, and Hiroyuki Nakayama ${ }^{1}$ \\ ${ }^{1}$ Department of Veterinary Pathology, Graduate School of Agricultural and Life Sciences, The University of Tokyo, 1-1-1 Yayoi, \\ Bunkyo-ku, Tokyo 113-8657, Japan \\ ${ }^{2}$ Pathology Group, Toxicology and Pharmacokinetics Laboratories, Pharmaceutical Research Laboratories, Toray Industries, Inc., \\ 6-10-1 Tebiro, Kamakura-shi, Kanagawa 248-8555, Japan
}

\begin{abstract}
In the present study, we evaluated the influence of intraperitoneal administration of 1-methyl-4-phenyl-1,2,3,6-tetrahydropyridine (MPTP) or 1-methyl-4-phenylpyridinium $\left(\mathrm{MPP}^{+}\right)$on the placenta. There was no increase in apoptotic cells in the placentas of C57BL $/ 6$ mice treated with $25.0 \mathrm{mg} / \mathrm{kg}$ MPTP or $17.1 \mathrm{mg} / \mathrm{kg} \mathrm{MPP}^{+}$, indicating that a single injection of the chemicals may induce very slight cytotoxicity in the placenta at $12 \mathrm{hr}$ after administration. The decrease in the expression of monoamine oxidase (MAO)-A in the labyrinth zone and that of MAO-B in the basal zone may be due to the decrease in cell activity, whereas the increase of MAO-B expression in the labyrinth zone after MPTP treatment may be due to a responsive reaction caused by MPTP, one of the substrates of MAO-B. The results represent histological evidence that MAO-B may be involved in the metabolism of MPTP to MPP in the labyrinth zone of the mouse placenta. In the present study, no increase in apoptotic cells indicates that MPTP and $\mathrm{MPP}^{+}$are hardly toxic to the placenta, and the histological change in MAO-B expression may indicate the possibility of involvement of placental MAO-B in MPTP metabolism. (DOI: 10.1293/tox.26.73; J Toxicol Pathol 2013; 26: 73-77)
\end{abstract}

Key words: C57BL/6 mice, placenta, MPTP (1-methyl-4-phenyl-1,2,3,6-tetrahydropyridine), MPP ${ }^{+}$(1-methyl-4-phenylpyridinium), MAO-B (monoamine oxidase B)

1-Methyl-4-phenyl-1,2,3,6-tetrahydropyridine (MPTP) toxicity has been demonstrated to cause damage to the central nervous system (CNS), especially to the dopaminergic neurons in the nigrostriatal system ${ }^{1-4}$. In adult C57BL/6 mice, MPTP enters into the brain through the blood-brain barrier $(\mathrm{BBB})$ and is converted to 1-methyl-4-phenylpyridinium $\left(\mathrm{MPP}^{+}\right)$by monoamine oxidase $(\mathrm{MAO})-\mathrm{B}^{5,6}$. $\mathrm{MPP}^{+}$ is then taken up into a neuronal cell and ultimately causes cell death ${ }^{7,8}$.

There has been much research on the neurotoxicity of MPTP in the mouse embryo. Chronic MPTP exposure during the organogenesis period reduced the fetal weight, motor activity, number of striatal tyrosine hydroxylase (TH)positive cells, and amounts of dopamine and homovanillic acid ${ }^{9}$. In our previous study, a single MPTP or $\mathrm{MPP}^{+}$exposure at pregnancy day (PD) 12 led to an increase in apoptotic cells and decrease in TH-positive cells in the CNS of the embryo $^{10}$. MPTP and MPP ${ }^{+}$injected into a dam and reaching the embryo would have to have crossed the placenta.

Received: 7 March 2012, Accepted: 10 December 2012 *Corresponding author: T Sai (e-mail: Takafumi_Sai@nts.toray. co.jp)

(C)2013 The Japanese Society of Toxicologic Pathology

This is an open-access article distributed under the terms of the Creative Commons Attribution Non-Commercial No Derivatives (by-ncnd) License $<$ http://creativecommons.org/licenses/by-nc-nd/3.0/> .
However, there are only a few reports dealing with the placental transmission of $\mathrm{MPTP}^{11,12}$.

In the embryonic part of the placenta, maternal and embryonic blood is separated by the trophoblast layer in the labyrinth zone ${ }^{13,14}$. A variety of materials such as oxygen, nutrients, waste products, and so on are exchanged between the maternal and embryonic plasma through this layer ${ }^{13}$. The trophoblast layer is composed of syncytiotrophoblasts, cytotrophoblasts, connective tissue and the embryonic capillary endothelium ${ }^{15,16}$, and the penetration limit of materials through this layer is called the "blood-placental barrier" 14,15 . On PD 12 in the mouse, maternal-embryonic transfer occurs primarily through the definitive chorioallantoic placenta, although mice also possess an inverted yolk sac placenta that can function as a major conduit for transfer $^{16}$. Low molecular weight materials, large molecules that undergo pinocytosis or receptor-mediated endocytosis (like IgG) can gain access to the embryonic blood stream ${ }^{16}$.

In the present study, we evaluated the influence of MPTP on the placenta and metabolism from MPTP to MPP in the placenta.

Pregnant C57BL/6J mice at PD 11 were obtained from Charles River Laboratories Japan (Yokohama, Japan). They were housed in metal cages under controlled housing conditions (temperature, $23 \pm 2{ }^{\circ} \mathrm{C}$; relative humidity, $55 \pm 5 \%$; light/dark cycle, 12/12 hr) and fed commercial pellets (MF; Oriental Yeast., Tokyo, Japan) and water ad libitum. MPTP- 
$\mathrm{HCl}$ (Sigma, St. Louis, MO, USA) and MPP-Iodide (Sigma) were dissolved in saline. In previous acute toxicity research, a single injection (about $30 \mathrm{mg} / \mathrm{kg})^{17,} 18$ of MPTP-HCl or a single $(12.5-25.0 \mathrm{mg} / \mathrm{kg})$ of MPP-Iodide ${ }^{19,20}$ was used. In a preliminary study, pregnant mice at PD 12 were injected i.p. with $12.5,25.0$ or $50.0 \mathrm{mg} / \mathrm{kg}$ MPTP-HCl (2 mice, respectively) or $8.6,17.1$ or $34.2 \mathrm{mg} / \mathrm{kg}$ MPP-Iodide (2 mice, respectively). The majority of the mice treated with $50.0 \mathrm{mg} /$ $\mathrm{kg}$ MPTP-HCl or $34.2 \mathrm{mg} / \mathrm{kg}$ MPP-Iodide at PD 12 died (1 of 2 mice and 2 of 2 mice, respectively), and no changes in performance status were observed in the mice trated with 12.5 $\mathrm{mg} / \mathrm{kg}$ MPTP-HCl or $8.6 \mathrm{mg} / \mathrm{kg}$ MPP-Iodide at PD 12 (1 of 2 mice and 2 of 2 mice, respectively). Hence injection doses of 25.0 and $17.1 \mathrm{mg} / \mathrm{kg}$ were determined for MPTP-HCl and MPP-Iodide, respectively. Eight pregnant mice were injected i.p. with $25.0 \mathrm{mg} / \mathrm{kg}$ MPTP-HCl (4 mice) or $17.1 \mathrm{mg} / \mathrm{kg}$ MPP-Iodide (4 mice) at PD 12. As a control, 4 mice were i.p. injected with an equivalent volume of saline $(10.0 \mathrm{ml} /$ $\mathrm{kg}$ ). At $12 \mathrm{hr}$ after treatment, mice were sacrificed by exsanguination under a deep anesthesia with diethyl ether. All procedures used in the present study were approved by the Committee of Animal Experiments of the Graduate School of Agricultural and Life Sciences, the University of Tokyo.

Two randomly chosen placentas per dam were fixed in a $10 \%$ neutral-buffered formalin solution. Each placenta was cut along the central axis into 2 pieces, and one of the pieces was embedded in paraffin and a sliced serially from the cut surface to obtain large sections and observe both central and peripheral zones. Four $\mu \mathrm{m}$-thick sections were stained with hematoxylin-eosin (HE). Apoptotic cells containing fragmented DNA were detected by the TdTmediated dUTP nick end labeling (TUNEL) method using an ApopTag Peroxidase In Situ Apoptosis Detection Kit (Millipore, Temecula, CA, USA) according to the manufacturer's instructions. The histological sections were then counterstained with methyl green. Immunohistochemistry was performed by the EnVision method (Dako, Carpinteria, CA). Deparaffinized sections were first autoclaved at $120^{\circ} \mathrm{C}$ for $15 \mathrm{~min}$ in $10 \mathrm{mM}$ citrate buffer ( $\mathrm{pH} \mathrm{6.0)} \mathrm{for} \mathrm{antigen} \mathrm{re-}$ trieval. The sections were then treated with $1 \%$ hydrogen peroxide-methanol at room temperature for $30 \mathrm{~min}$ and then with $8 \%$ skim milk-Tris-buffered saline at $37^{\circ} \mathrm{C}$ for $30 \mathrm{~min}$ for protection from nonspecific reactions. The sections were then incubated with one of the following primary antibodies, which have species specificity for the human, mouse and rat, at $4^{\circ} \mathrm{C}$ for $18 \mathrm{hr}$ : rabbit anti-cleaved caspase-3 (1:200; Cell Signailing Technology, Danvers, MA, USA), rabbit antiMAO-A (1:300; Proteintech Group, Chicago, IL, USA) and rabbit anti-MAO-B (1:30; Proteintech Group). Following the secondary antibody reaction with the EnVision Anti-Rabbit Conjugation System (Dako) at $37^{\circ} \mathrm{C}$ for $1 \mathrm{hr}$, the reaction products were finally visualized with $0.05 \%$ 3-3'-diaminobenzidine and $0.03 \%$ hydrogen peroxide in Tris- $\mathrm{HCl}$ buffer. Counterstaining was performed with methyl green.

MAO-A- and MAO-B-positive areas in the placenta were measured using image analysis software, Image J (NIH, Bethesda, MD, USA) and Adobe Photoshop 6.0 (Adobe Sys- tems, San Jose, CA, USA). All results are expressed as the mean \pm standard error (SE). Statistical analyses were carried out with the $F$-test and Student's $t$-test or Aspen-Welch test to assess differences between data groups. Differences were considered significant when $P<0.05$.

Decreases in locomotor activity, hypothermia and convulsion were observed in the majority of MPTP or $\mathrm{MPP}^{+}$ treated pregnant mice. No significant morphological changes were observed in the placentas of the MPTP or MPP treated mice (Fig. 1b-g). Very few apoptotic (TUNEL-positive and/or cleaved caspase-3-positive) cells were observed in the labyrinth zone of the placenta in the control and MPTP- or $\mathrm{MPP}^{+}$-treated mice (data not shown). MAO-A was expressed in the trophoblast and capillary endothelium of the labyrinth zone (Fig. $2 \mathrm{a}-\mathrm{c}$ ) of the mice, and the positive area was decreased by treatment with either MPTP or $\mathrm{MPP}^{+}$(Fig. 2d). However, the expression was not observed in the basal zone (data not shown). MAO-B was expressed in the trophoblast and capillary endothelium in the labyrinth zone (Fig. $3 \mathrm{a}-\mathrm{c}$ ) and spongiotrophoblast and trophoblastic giant cell in the basal zone (Fig. $3 \mathrm{~d}-\mathrm{f}$ ) of mice. In the labyrinth zone, the MAO-B-positive area was increased by treatment with MPTP (Fig. 3g). However, in the basal zone, the area was decreased by treatment with either MPTP or $\mathrm{MPP}^{+}$(Fig. 3h).

There were no morphological changes and no increases in apoptotic cells in the placentas of mice treated with MPTP or $\mathrm{MPP}^{+}$, indicating that a single injection of MPTP or $\mathrm{MPP}^{+}$does not induce severe cytotoxicity (e.g., irreversible changes) in placental cells.

MAO-A-immunopositive cells were observed only in the labyrinth zone, not in the basal zone, which was in accordance with the results of a previous study ${ }^{21}$; however, MAO-B-positive cells were observed in both the labyrinth zone and basal zone as in previous studies ${ }^{22,23}$. The results indicate that the antibodies used in the present study have high specificity for MAO-A and MAO-B, respectively.

Immunohistochemical expressions of MAO-A in the labyrinth zone and MAO-B in the basal zone were decreased by treatment with MPTP or $\mathrm{MPP}^{+}$. Such decreases in MAO-A and MAO-B may be related to the cytotoxicity in the spongiotrophoblast and trophoblast induced by MPTP and $\mathrm{MPP}^{+}$, though we have no other data from quantitative analyses, such as biochemical assays with internal controls. On the other hand, a significant increase in MAO-B-positive cells in the labyrinth zone $12 \mathrm{hr}$ after MPTP treatment was demonstrated in the present study, in accordance with the results of a previous study on embryonic and newborn mice $^{24}$. We speculate that the increase in MAO-B expression is a kind of responsive reaction to injected MPTP, a substrate for MAO-B. If so, MAO-B might be involved in the metabolism of MPTP to $\mathrm{MPP}^{+}$in the labyrinth zone of the mouse placenta.

Previous studies indicated that materials with molecular weights of less than $600 \mathrm{Da}$, including MPTP and $\mathrm{MPP}^{+}$ (molecular weights are 173.3 Da and 170.3 Da, respectively), easily transfer to the embryo through passive diffusion ${ }^{25}$. 

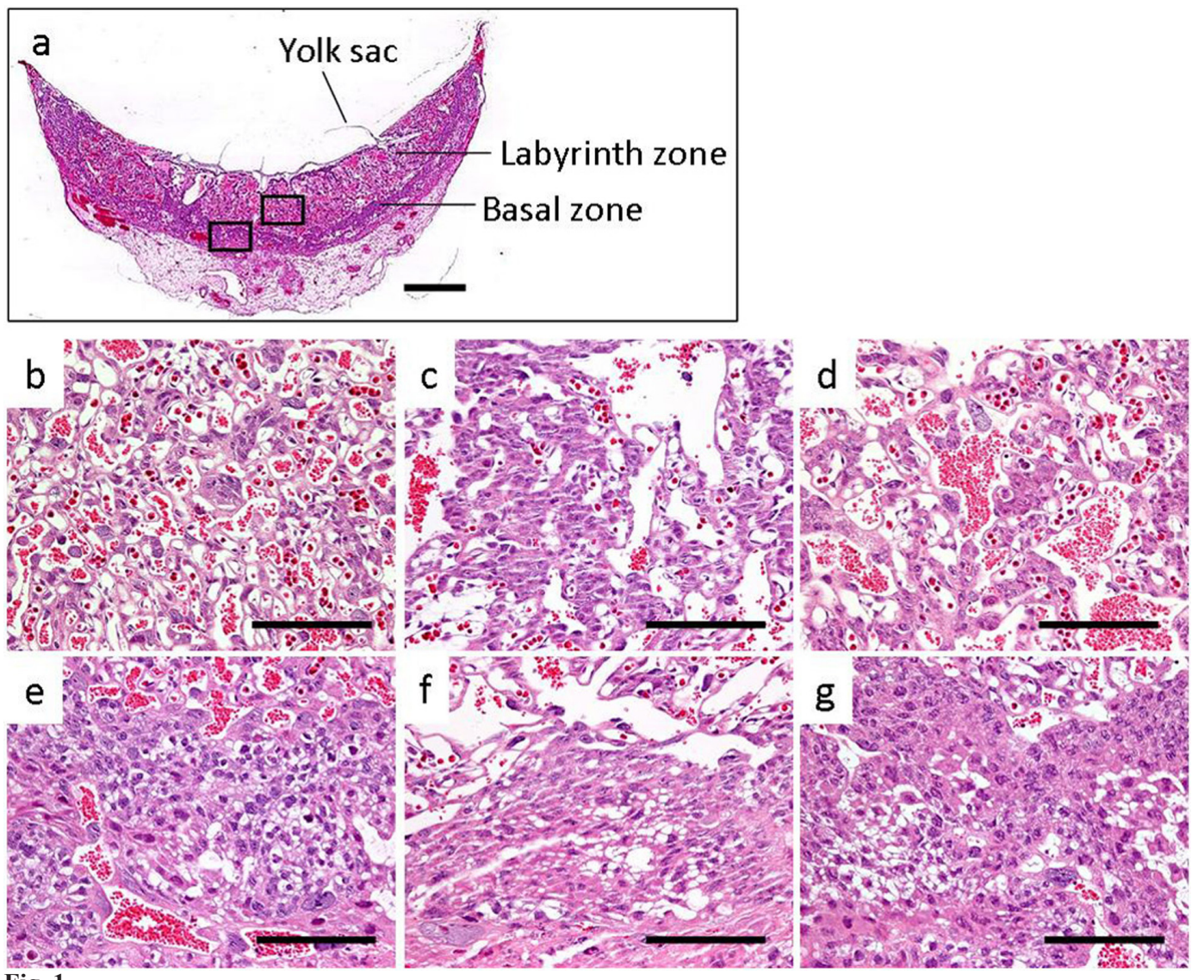

Fig. 1.
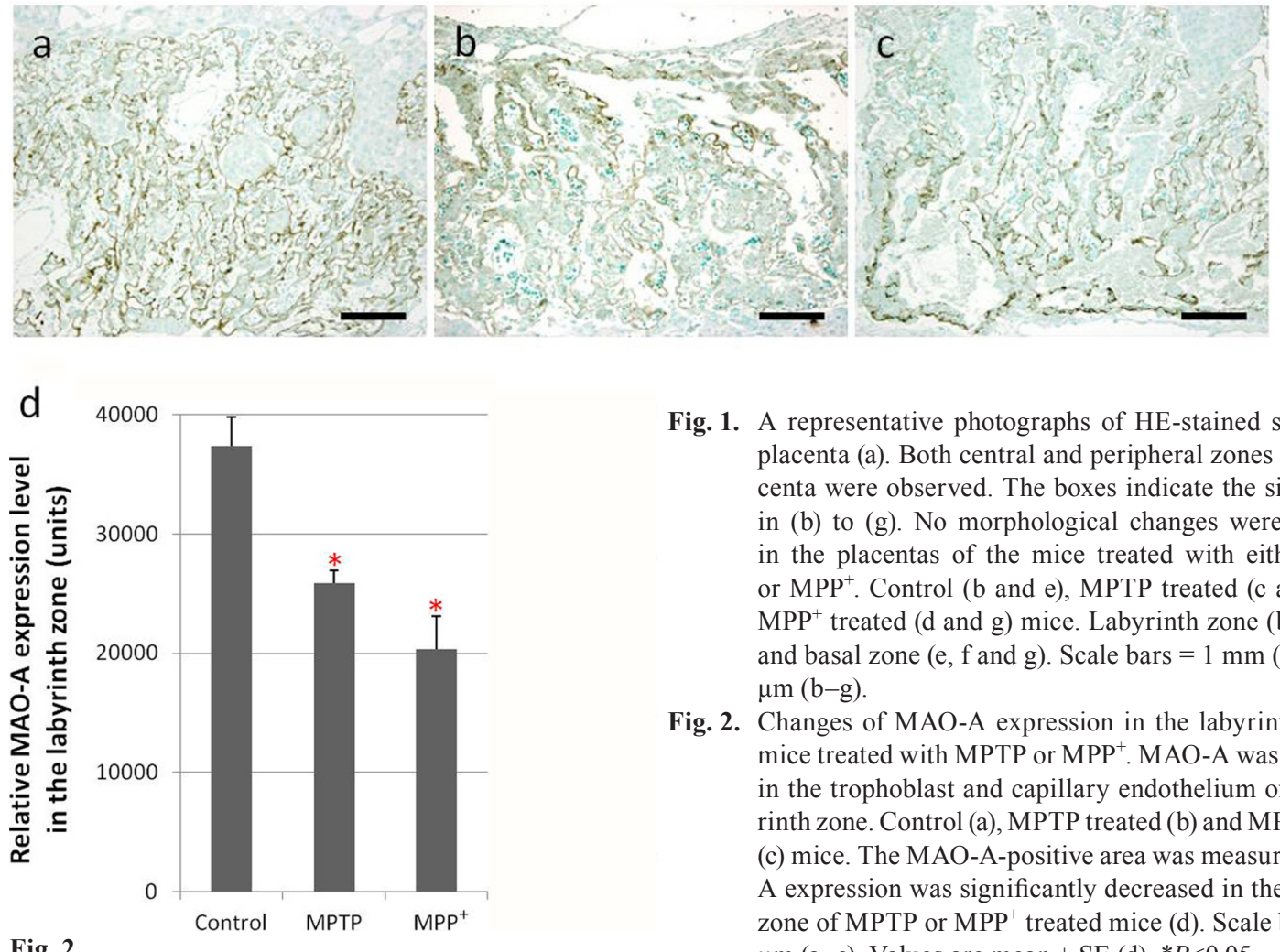

Fig. 1. A representative photographs of HE-stained sections of placenta (a). Both central and peripheral zones of the placenta were observed. The boxes indicate the sites shown in (b) to (g). No morphological changes were observed in the placentas of the mice treated with either MPTP or $\mathrm{MPP}^{+}$. Control (b and e), MPTP treated (c and f) and $\mathrm{MPP}^{+}$treated (d and g) mice. Labyrinth zone (b, c and d) and basal zone (e, $f$ and $g$ ). Scale bars $=1 \mathrm{~mm}$ (a) and 100 $\mu \mathrm{m}(\mathrm{b}-\mathrm{g})$.

Fig. 2. Changes of MAO-A expression in the labyrinth zone of mice treated with MPTP or MPP ${ }^{+}$. MAO-A was expressed in the trophoblast and capillary endothelium of the labyrinth zone. Control (a), MPTP treated (b) and $\mathrm{MPP}^{+}$treated (c) mice. The MAO-A-positive area was measured. MAOA expression was significantly decreased in the labyrinth zone of MPTP or $\mathrm{MPP}^{+}$treated mice (d). Scale bars $=100$ $\mu \mathrm{m}(\mathrm{a}-\mathrm{c})$. Values are mean $\pm \mathrm{SE}(\mathrm{d}) .{ }^{*} P<0.05$. 

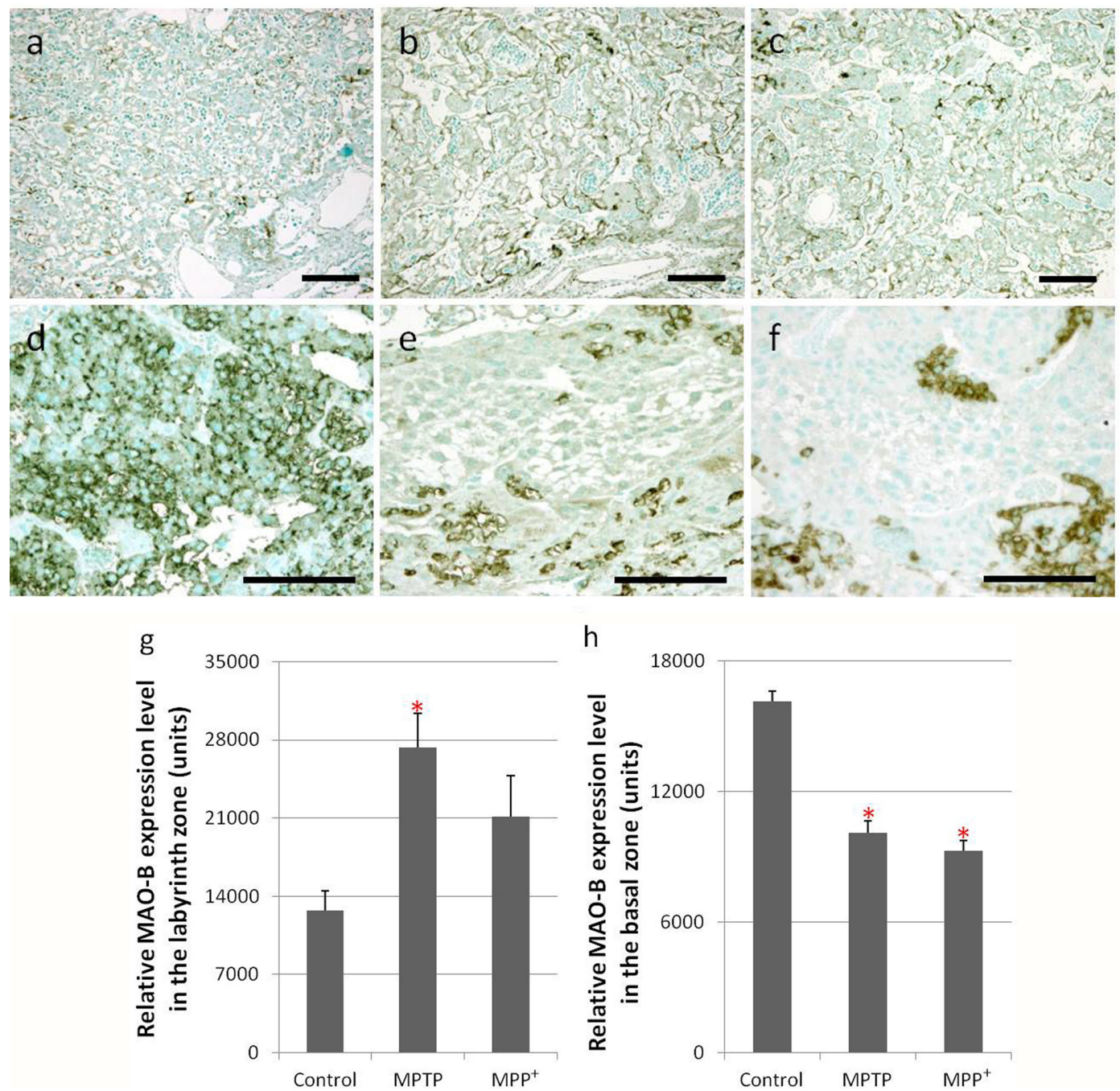

Fig. 3. Changes of MAO-B expression in the labyrinth zone and basal zone of mice treated with MPTP or MPP ${ }^{+}$. MAO-B was expressed in the trophoblast and capillary endothelium in the labyrinth zone and in the spongiotrophoblast and trophoblastic giant cell of the basal zone. Control (a and d), MPTP treated (b and e) and $\mathrm{MPP}^{+}$treated (c and f) mice. Labyrinth zone (a, b and c) and basal zone (d, e and f). MAO-B-positive areas in the labyrinth zone and basal zone were measured ( $\mathrm{g}$ and $\mathrm{h}$ ). MAO-B expression was significantly increased in the labyrinth zone of MPTP treated mice (g). MAO-B expression was significantly decreased in the basal zone of mice treated with MPTP or $\mathrm{MPP}^{+}(\mathrm{h})$. Scale bars $=100 \mu \mathrm{m}(\mathrm{a}-\mathrm{f})$. Values are mean $\pm \mathrm{SE}$ (g and h). $* P<0.05$.

We also showed the embryonic neuronal toxicity of MPTP or $\mathrm{MPP}^{+}$injected i.p. in the maternal body ${ }^{10}$. MPTP and $\mathrm{MPP}^{+}$, which is metabolized from MPTP, in the maternal body and placenta can pass through the placenta freely and transfer to the embryo.

The present study demonstrated that MPTP and $\mathrm{MPP}^{+}$ are hardly toxic to the mouse placenta and that MAO-B expressed in the placenta may be involved in the metabolism of MPTP to MPP ${ }^{+}$. However, the mechanisms of the MAO$\mathrm{B}$ expression change in the labyrinth zone and basal zone should be further examined.

\section{References}

1. He XJ, Yamauchi H, Uetsuka K, and Nakayama H. Neurotoxicity of MPTP to migrating neuroblasts: studies in acute and subacute mouse models of Parkinson's disease. Neurotoxicology. 29: 413-420. 2008. [Medline] [CrossRef]

2. He XJ, and Nakayama H. Neurogenesis in neurotoxin-induced animal models for Parkinson's desease- A review of current status. J Toxicol Pathol. 22: 101-108. 2009. [Medline] [CrossRef]

3. Dehay B, Bove J, Rodriguez-Muela N, Perier C, Recasens A, Boya P, and Vila M. Pathogenic lysosomal depletion in Parkinson's disease. J Neurosci. 30: 12535-12544. 2010. [Medline] [CrossRef]

4. Ito T, Suzuki K, Uchida K, and Nakayama H. 1-Methyl- 
4-phenyl-1,2,3,6-tetrahydropyridine (MPTP)-induced neuroblastic apoptosis in the subventricular zone is caused by 1-methy-4-phenylpiridinium $(\mathrm{MPP}(+))$ converted from MPTP through MAO-B. Exp Toxicol Pathol., in press. [Medline]

5. He XJ, Uetsuka K, and Nakayama H. Neural progenitor cells are protected against MPTP by MAO-B inhibitors. Neurotoxicology. 29: 1141-1146. 2008. [Medline] [CrossRef]

6. Sonsalla PK, Wong LY, Winnik B, and Buckley B. The antiepileptic drug zonisamide inhibits MAO-B and attenuates MPTP toxicity in mice: clinical relevance. Exp Neurol. 221: 329-334. 2010. [Medline] [CrossRef]

7. Reinhard JF Jr, Diliberto EJ Jr, Viveros OH, and Daniels AJ. Subcellular compartmentalization of 1-methyl-4-phenylpyridinium with catecholamines in adrenal medullary chromaffin vesicles may explain the lack of toxicity to adrenal chromaffin cells. Proc Natl Acad Sci. 84: 8160-8164. 1987. [Medline] [CrossRef]

8. Schapira AH. Mitochondrial dysfunction in Parkinson's disease. Cell Death Differ. 14: 1261-1266. 2007. [Medline] [CrossRef]

9. Schmahl W, and Beat U. Placental toxicity of 1-methyl4-phenyl-1,2,3,6-tetrahydropyridine (MPTP) in mice. Toxicology. 67: 63-74. 1991. [Medline] [CrossRef]

10. Sai T, Uchida K, and Nakayama H. Acute toxicity of MPTP and $\mathrm{MPP}^{+}$in the brain of embryo and newborn mice. Exp Toxicol Pathol. 65: 113-119. 2013. [Medline] [CrossRef]

11. Ohya Y, Naoi M, Ochi N, Mizutani N, Watanabe K, and Nagatsu T. Uptake of N-methyl-4-phenyl-1,2,3,6-tetrahydropyridine (MPTP) and the N-methyl-4-phenylpyridinium ion $(\mathrm{MPP}+)$ into fetal mouse brain through the placenta. Neurosci Lett. 105: 221-226. 1989. [Medline] [CrossRef]

12. Schmahl W, and Usler B. Placental toxicity of 1-methyl4-phenyl-1,2,3,6-tetrahydropyridine (MPTP) in mice. Toxicology. 25: 63-74. 1991. [Medline] [CrossRef]

13. Riquelme G. Placental syncytiotrophoblast membranesdomains, subdomains and microdomains. Placenta. 32: S196-202. 2011. [Medline] [CrossRef]

14. Furukawa S, Hayashi S, Usuda K, Abe M, Hagio S, and Ogawa I. Toxicological Pathology in the Rat Placenta. J toxicol Pathol. 24: 95-111. 2011. [Medline] [CrossRef]

15. Mori M, Ishikawa G, Luo SS, Mishima T, Goto T, Robinson JM, Matsubara S, Takeshita T, Kataoka H, and Takizawa T. The cytotrophoblast layer of human chorionic villi becomes thinner but maintains its structural integrity during gersta- tion. Biol Reprod. 76: 164-172. 2007. [Medline] [CrossRef]

16. DeSesso JM, Williams AL, Ahuja A, Bowman CJ, and Hurtt ME. The placenta, transfer of immunoglobulins, and safety assessment of biopharmaceuticals in pregnancy. Crit Rev Toxicol. 42: 185-210. 2012. [Medline] [CrossRef]

17. Chen JF, Steyn S, Staal R, Petzer JP, Xu K, Van der Schyf CJ, Castagnoli K, Sonsalla PK, and Castagnoli N. Schwarzschild MA. 8-(3-Cholorostyryl) caffeine may attenuate MPTP neurotoxicity through dual actions of monoamine oxidase inhibition and $\mathrm{A}_{2 \mathrm{~A}}$ receptor antagonism. J Biol Chem. 277: 36040-36044. 2002. [CrossRef]

18. Quinn LP, Crook B, Hows ME, Vidgeon-Hart M, Chapman H, Upton N, Medhurst AD, and Virley DJ. The PPAR $\gamma$ agonist pioglitazone is effective in the MPTP mouse model of Parkinson's disease through inhibition of monoamine oxidase B. Br J Pharmacol. 154: 226-233. 2008. [Medline] [CrossRef]

19. Sundstöm E, Goldstein M, and Jonsson G. Uptake inhibition protects nigro-striatal dopamine neurons from the neurotoxicity of 1-methyl-4-phenylpyridine (MPP+) in mice. Eur J Pharmacol. 131: 289-292. 1986. [Medline] [CrossRef]

20. Freyaldenhoven TE, Ali Syed F, and Hart RW. MPTP- and $\mathrm{MPP}^{+}$-induced effects on body temperature exhibit ageand strain-dependence in mice. Brain Res. 688: 161-170. 1995. [Medline] [CrossRef]

21. Verhaagh S, Barlow DP, and Zwart R. The extraneuronal monoamine transporter Slc22a3/Orct3 co-localizes with the Maoa metabolizing enzyme in mouse placenta. Mech Dev. 100: 127-130. 2001. [Medline] [CrossRef]

22. Riley LA, Waguespack MA, and Denney RM. Characterization and quantitation of monoamine oxidases $\mathrm{A}$ and $\mathrm{B}$ in mitochondria from human placenta. Mol Pharmacol. 36: 54-60. 1989. [Medline]

23. Auda GR, Kirk SH, Billett MA, and Billet EE. Localization of Monoamine Oxidase mRNA in Human Placenta. J Histochem Cytochem. 46: 1393-1400. 1998. [Medline] [CrossRef]

24. Sai T, Uchida K, and Nakayama H. Involvement of monoamine oxidase-B in the acute neurotoxicity of MPTP in embryonic and newborn mice. Exp Toxicol Pathol., in press. [Medline]

25. Ceckova-Novotna M, Pavek P, and Staud F. P-glycoprotein in the placenta: expression, localization, regulation and function. Reprod Toxicol. 22: 400-410. 2006. [Medline] [CrossRef] 